\title{
Politico-Cultural Prerequisites for Protecting the Oromo National Interest
}

\author{
Asafa Jalata \\ Department of Sociology, University of Tennessee, Knoxville, USA \\ Email: ajalata@utk.edu
}

How to cite this paper: Jalata, A. (2019). Politico-Cultural Prerequisites for Protecting the Oromo National Interest. Sociology Mind, 9, 95-113.

https://doi.org/10.4236/sm.2019.91006

Received: September 29, 2018

Accepted: December 10, 2018

Published: December 13, 2018

Copyright $\odot 2019$ by author and Scientific Research Publishing Inc. This work is licensed under the Creative Commons Attribution International License (CC BY 4.0).

http://creativecommons.org/licenses/by/4.0/

\begin{abstract}
The main objective of this paper is to identify and critically examine the main cultural and political prerequisites that the Oromo nation needs to achieve its objectives of political sovereignty and egalitarian democracy and to protect its national interest. First, the paper briefly provides background information on the Oromo cultural and institutional foundations. Second, it identifies and explains the major challenges that Oromo nationalists need to overcome to fulfill the objectives of the Oromo national movement. Third, the piece deals with the current cultural and political strengths and challenges and the main ideological and political roadmaps, which are necessary to fully achieve the political objectives of the Oromo nation and to protect the Oromo national interest.
\end{abstract}

\section{Keywords}

Oromo National Interest, (Oromummaa) Oromo Nationalism, Gadaal Siiqqee (Oromo Democracy), Oromia (Oromo Nation), Qeerroo/ Qarree (Oromo Youth)

\section{Introduction}

A nation that is prevented from freely developing its political and cultural institutions by colonialism, and forced to serve the interest of another society, suffers from political domination, exploitation, underdevelopment, and poverty (Rodney, 1972; Jalata, 2001). Similarly, the Oromo nation has been denied the right to develop its independent cultural, political, and economic institutions since its colonization and incorporation into the Ethiopian Empire. As explained elsewhere (Jalata, 2005 [1993], 2010), there have been several internal and external problems that have contributed to the destruction of Oromo cultural and political institutions and the subordination of the Oromo national interest to that of the Ethiopian colonial state and its regional and global supporters. Ethiopian 
colonialism has partioned the Oromo society mentally and geographically in order to divide and conquer and to undermine the Oromo identity and national unity.

Specifically, successive Ethiopian colonial elites have effectively destroyed/ suppressed Oromo cultural foundations and political institutions, created subservient Oromo leaders, replaced Oromummaa (Oromo national culture, identity and ideology) by Ethiopianism, partitioned and renamed Oromian territories, looted Oromo economic resources, and dehumanized the Oromo society (Jalata, 2010). The Oromo national movement emerged in the 1960s and 1970s to solve these complex problems and to protect the Oromo national interest (Jalata, 2007). The paper briefly provides background information on the Oromo cultural and institutional foundations; identifies and explains the major challenges of the Oromo national movement; and explores the current Oromo cultural and political strengths and challenges and the main ideological and political roadmaps of the Oromo national struggle in relation to Oromia's national interest.

\section{Looking Back at Oromo Cultural Foundations and Institutions}

A clear understanding of the relationship between culture and politics is very important because of the influence of cultural capital on the development of democracy ${ }^{1}$. The histories of Oromia and Ethiopia demonstrate that ignoring the cultural capital of the indigenous democracy such as that of the Oromo called the gadaa/siiqqee ${ }^{2}$ system and imposing an authoritarian/ethnocratic state on various national groups produce continuous economic and political crises. Without critically and thoroughly addressing and solving these complex problems, the Oromo national movement cannot adequately achieve its political objectives and protect the Oromo national interest. Before its colonization, Biyya Oromo or Oromia (the Oromo country) was sovereign under the gadaa republic (Baissa, 2004, 1971, 1993; Lepisa, 1975). The Oromo people started to practice their democratic system more than 4000 years ago (Jaarraa \& Saaddoo, 2011: p.

\footnotetext{
${ }^{1}$ As Pierre Bourdieu notes: "as economic capital, which is ... directly convertible into money and may be institutionalized in the forms of private property rights; as cultural capital, which is convertible ... into economic capital and may be institutionalized in the forms of [position of power] and educational qualifications; and as social capital, made of social obligations ("connections"), which is convertible ... into economic capital and may be institutionalized in the form of a title of nobility." His theories of cultural capital should not be limited to formal education, and it must also include informal education, which plays a significant role in maintaining status quo in class, gender and ethno-national hierarchies. See,

https://www.marxists.org/reference/subject/philosophy/works/fr/bourdieu-forms-capital.htm, accessed on 11/09/17.

${ }^{2}$ Gadaa was a form of constitutional government of the Oromo. It was practiced through the election of political leaders by adult male suffrage every eight years; corrupt leaders would be removed from power through buqisu (recall) before their official tenure. See Asmarom Legesse, Oromo Democracy: An Indigenous African Political System, (Trenton, NJ: The Red Sea Press, Inc., 2006). Siqqee is a sub-set of gadaa, and I use the terms gadaa/siqqee to designate the concept of Oromo democracy.
} 
61). The Oromo oral tradition indicates that the original center of Abbaa Gadaa, the president of the Oromo assembly known as caffee, and the center of Abbaa Muda, the leader of Oromo indigenous religion known as Waaqeefannaa, was Abbaya or Mormor (ancient name for the Blue Nile) until it moved to Odaa Nabee in the $5^{\text {th }}$ century A. D. (Oromia Cultural Tourism Bureau (OCTB), 2006: p. 74). A few Oromo branches such as Galan and Yaya settled for many centuries on both sides of the Blue Nile, the northern part of the Shawa Plateau, before the Christian immigrants began to arrive between the $11^{\text {th }}$ and $13^{\text {th }}$ centuries (Bulcha, 2016; Hassen, 2015).

The gadaa system evolved through the processes known as cinna (decentralization based on extended clan families) and haroomisa (renewal and reorganization of gadaa at national level) (OCTB, 2006). The center of gadaa gradually moved to Odaa Nabee. Currently, there is not enough information on the renewal of gadaa at Odaa Mormor and its movement to Odaa Nabee, near Finfinnee (central Oromo country). According to the Oromo oral tradition, the central gadaa system, caffee (Oromo assembly) was practiced at Odaa Nabee from 5 century A. D. to 756 A. D. (OCTB, 2006). The $8^{\text {th }}$ century A. D. was characterized as the year of cinna gadaa (decentralization) and the $1116 \mathrm{~A}$. D. was called the year of haroomsa gadaa (renewal, centralization and consolidation) (OCTB, 2006: p. 52). The Oromo were facing both the Muslim and Christian empire builders who were competing with each other on the issues of religion, land and other economic resources. The Muslim empire builders, which started in the late $10^{\text {th }}$ century, and the Christian empire builders, which consolidated after $13^{\text {th }}$ century, engaged in religious and political wars and destabilized the Oromo society for many centuries in the Horn of Africa (OCTB, 2006: pp. 94-95). Between the $13^{\text {th }}$ and $14^{\text {th }}$ centuries, the Oromo people were attacked by Abyssinian Christians from the North and by Muslim Somalis from the South East (Jaarraa \& Saaddo, 2011). Both groups wanted to dismantle the Oromo identity, culture, religion, and the gadaa system, and to take over the Oromo country. These external pressures created instability that negatively affected the efficient functioning of the gadaa system in the Tulama Oromo (Northern Shawa) and instigated the movement of the Oromo towards the south, and the decentralization of the gadaa system into clan-based autonomous administrations. These factors facilitated the transfer of the center of the gadaa system from Odaa Nabee (near Finfinnee) to Odaa Roba and then to Madda Walaabuu (the stream of liberty), located in Bale (Jaarraa \& Saaddo, 2011).

From around 1316 to 1378 , Odaa Roba started to function as the center of an Oromo politico-religious system by replacing Odaa Nabee, and then the center was transferred to Madda Walaabuu in 1450 (Jaarraa \& Saaddo, 2011). In the same year, the Abbaa Muda, the main Oromo religious figure, moved to Madda Walaabuu (OCTB, 2011). When the Abyssinian Christian kingdom attacked the Tulama Oromo, the Muslim Somali empire builders also attacked the Oromo branches who were living in the area that is currently called Somalia (OCTB, 2011). After the decentralization of the gadaa system at Odaa Nabee because of 
the external pressure from the Christian kingdom, "the total gadaa revival was successfully completed at the Odaa Roba 'caffee' center in 1316. It should be noted here that ... the movement of gadaa revival took place at Odaa Mormor, Odaa Nabee, Odaa Roba and Madda Walaabuu shows that two different institutions were working for a common goal. When gadaa revival was taking place at Odaa Nabee, it served as the center of both politics and religion for the Oromo clans living in the area" (OCTB, 2011: p. 56). The renewal movement of the gadaa system occurred at Odaa Roba in Bale by replacing "Odaa Nabee, which had been a politico-religious center for several hundred years before the $14^{\text {th }}$ century," and "Odaa Roba had become a new holy politico-religious center of the Oromo people at large that had been periodically visited by the various representatives of Oromo groups from all directions for such celebrations like Jilaa Gada and Mudaa [pilgrim]" (OCTB, 2011: pp. 90-91).

Gradually the politico-religious center of Odaa Roba moved to Madda Walaabuu for reasons that are not clear at present. The Bale Oromo living around Madda Walaabu also started to reorganize and reconsolidate their power starting from $11^{\text {th }}$ century (Jaarraa \& Saaddo, 2011: p. 104). The general assembly of the Oromo nation was held between 1518 and 1519 for six months at Madda Walaabuu to discuss and deliberate how to liberate the Oromo country from the Christian and Muslim invaders; delegates from different parts of the Oromo country participated on this assembly (Jaarraa \& Saaddo, 2011). Particularly, the Oromo from Tulama sent delegates of twelve people led by Dachaasa to Odaa or Madda Walaabuu (Jaarraa \& Saaddo, 2011). The main question Walaabuu Jiloo, Abbaa Gadaa of Madda Walaabuu, asked at the general assembly was "Maal Taana?" ("What are we going to be?") After thorough discussions and deliberations for six months, the general assembly defined the enemies of the Oromo people as those Christian and Muslim empire builders who were attacking the Oromo people in their own country to kill them, take their land and other resources, and to force them to abandon their culture, religion and identity. The assembly also passed major resolutions to mobilize the entire nation to liberate their country (Jaarraa \& Saaddoo, 2011). The Oromo people still have in their memory pool the name Madda Walaabuu because they started the defensive and liberation wars there in the early $16^{\text {th }}$ century.

The history of Madda Walaabuu demonstrates that the most significant revival and reorganization of the gadaa institution occurred at the beginning of $16^{\text {th }}$ century (Jaarraa \& Saaddoo, 2011: p. 96). Since the $16^{\text {th }}$ century, the renewal and reorganization of the gadaa system involved fundamental changes; these changes included rules, regulations and objectives. There were two main objectives: "Firstly, it was aimed [at] defending the gadaa system and the Oromo people from the pressure of Islam. Secondly, the change was sought to reinforce the military power of the people and enable them to regain their old area of settlement lost as the result of the incessant wars of the Christian and Muslim states ... The changes in ... the formulation of new rules and regulations were, therefore actions of paramount importance in order to realize those objectives" 
(OCTB, 2011: p. 96). Consequently, the Oromo decided "at least one Butta military campaign to be launched every eight years in all directions in order to regain the old settlement areas of the Oromo people who were forced to desert and unite them with their kinsmen that remained behind. [It] was [also] decided to strengthen Muda religious pilgrimage made to the seat of the Qaallu every eight years" (OCTB, 2011: pp. 96-97). In 1522, the Oromo started their resistance struggle to recover their lost homeland. This was before the Muslims seriously confronted Christian Abyssinia/Ethiopia in 1527.

The Muslims destroyed Christian rule and established their own under the leadership of one Ahmed Gragn for more than a decade in the Horn of Africa. The Oromo were caught in the wars of the Christian and Muslim empire-builders, and according to Darrel Bates (1979: p. 7), "The [Oromo] ... had suffered in their time from both parties, and were waiting in the wings for opportunities ... to recover lands which had been taken from them." The wars between Christians and Muslims endangered the Oromo's survival as a people. With the renewal and reorganization of gadaa, the Oromo carried out butta wars every eight years, when power transferred from one gadaa grade to the next. In the beginning of the 16th century, when they began to intensify their territorial recovery through the butta wars, all Oromo were under one gadaa government. This factor and the ability of the gadaa system to reconsolidate the people both militarily and organizationally enabled them to recover their lost territories and accommodate their increased population and stock (Legesse, 1973). Their movement and recovery signaled their survivability (Ta'a, 1986). The Oromo fought twelve butta wars between 1522 and 1618, recovering and reestablishing the Oromo country that is called Oromia today (Ta'a, 1986). In the course of their continued movements and their liberation struggle, different Oromo groups gradually established autonomous gadaa governments. At the same time, various Oromo groups kept their relations through the office of Abbaa Muuda (the father of anointment) (Ta'a, 1986) and formed alliances or confederations during times of difficulty (Etefa, 2012).

However, the development of class differentiation within the Oromo society in northern, central and western Oromia, external factors-such as Turko-Egyptian colonialism in eastern Oromia between 1875 and 1885 and European and Ethiopian colonialism-the emergence of an Oromo collaborator class, and the spread of Islam and Christianity undermined the political, military, and ritual/spiritual roles of the gadaa system. Both internal socio-economic transformations and external interactions with neighboring peoples slowly facilitated the emergence of class and the moottii system (kingdom) in some Oromo areas. As some Oromo clans moved to far-flung regions and interacted with Abyssinian and Omotic kingdoms and Nilo-Saharan societies and as they settled and engaged in farming and trade, they developed class differentiation that gradually led to the transformation of the gadaa system into the moottii system in northern, central and western Oromia. With the development of class differentiation, the egalitarian democratic system was challenged and replaced by the moottii 
system in some areas. Constant wars led to the evolution of the abba dulas (military leaders) to hereditary moottiis (leaders). In the $18^{\text {th }}$ century, the Wallo Oromo had replaced the gadaa administration with that of kingdom. In the Gibe region, the moottii system developed through confiscation of land, collection of booty, tribute and market dues, and through the establishment of hereditary rights to ownership of property and political office in the $19^{\text {th }}$ century. The emergence of powerful autocratic leaders and their private armies led to the control of marketplaces, trade routes and land, and the development of an agricultural economy that led to further class differentiation and the formation of the mootti system (Hassen, 1990).

The egalitarian democratic gadaa system was incompatible with the new moottii system due to the fundamental changes in the landholding system. In other words, the emergence of class differentiation and the rise of the Oromo kingdoms suppressed the gadaa system in some parts of Oromia.

For example, in the Gibe region, five Oromo states-Limmu-Ennarya, Guma, Jimma, Gera and Goma-emerged between the $17^{\text {th }}$ and $19^{\text {th }}$ centuries (Lewis, 2001). Here in the $17^{\text {th }}$ century, the differentiation of wealth went beyond the wealth of cattle when the sorressa (the wealthy merchant and landlord class) emerged. With the emergence of this wealthy class, the principle of adopting the conquered populations as "equal" through the mogassa process ended; the institutions of slavery and qubisisa (tenancy) emerged. The emergence of a hierarchical structure reduced the egalitarian aspects of the gadaa to religious rituals. The moottii (king) continuously accumulated wealth with incomes he extracted from tribute on the land and its products, and from commerce. This produce extraction enabled the moottii to create and maintain regulatory institutions like a military, bodyguards, and courts. Also, the emergence of moottii systems in Leqa-Naqamte and Leqa-Qellem, western Oromia, was actually based on the initiation of warfare and appropriation of rights to land and labor, control of trade and market places. Externally, the gadaa system was attacked and weakened in eastern Oromia by the Turko-Egyptian and Harari conspiracy. The interethnic alliance and interdependence between the Harari, residents of the walled city of Harar and the eastern Oromo was shattered when a faction of the former invited the Turko-Egyptian power to colonize the Hararge region in 1875. Between 1875 and 1885, the Harari retained their position and accumulated wealth at the cost of the majority Oromo under the Turko-Egyptian rule (Jalata, 2005[1993]).

Similarly, in the regions presently called Sidamo, Arssi, Bale, Illubabor, and Gamu Gofa and in some parts of Shawa, the gadaa system was suppressed by the alliance of global imperialism and Ethiopian colonialism. The capitalist penetration of the last decades of $19^{\text {th }}$ century laid the economic foundation of the modern Horn states, followed by the occupation of strategic positions by European powers along the Red Sea littoral. Generally speaking, the partition of the Horn of Africa in the last decades of the $19^{\text {th }}$ century, the alliance between European imperialists-namely France, England, and Italy-and Ethiopian warlords, and the colonization of Oromia ended Oromo statehood and sovereignty, which the 
Oromo national movement is currently struggling to restore. As an egalitarian system, gadaa did not compete well with hierarchical social systems that engaged in the extraction of economic surplus and political oppression by building a permanent professional bureaucracy, expanding formal education, and developing limited technological capabilities. The intervention of the Ethiopian and European powers through military, mercantile, colonial and neo-colonial forces in Oromo society demonstrated the challenge the Oromo political leadership was facing because of an externally imposed exploitative and oppressive social system. Because of the external influence and the internal weakness of the gadaa system after its decentralization, autocratic and hereditary chiefs emerged by overthrowing the democratically elected leadership in some parts of Oromia.

The historical legacy of Oromo political leadership is the sovereignty the Oromo experienced under the gadaa government and its egalitarian framework. Consequently, under the gadaa system, the Oromo society enjoyed relative peace, stability, sustainable development and political sovereignty although technologically and bureaucratically not well developed. The imposition of the Ethiopian colonial system and the emergence of the Oromo collaborator class had denied the Oromo the opportunity of rebuilding their national institutions and organizations. Consequently, the Oromo have been facing monumental external and internal challenges in rebuilding their national organizational capacity that could have helped them in reestablishing the rules of the game, and in building strong national organizations that could have effectively mobilized them to successfully carry out the national projects of liberation, egalitarian democracy, and development. The Ethiopian colonial state had partitioned the Oromo society physically and mentally, and the Oromo national movement did not yet destroy the foundations of these divisions. These divisions have undermined safuu (Oromo moral and ethical order) and the rules of the game that they used to have. Consequently, some Oromo individuals and groups have become the agents of the colonial system to benefit themselves and their colonial masters. The Ethiopian colonial state has used brute force and developed elaborated ideological mechanisms such as Ethiopianism to prevent the Oromo people from rebuilding their independent national institutions, organizations and leadership.

The rebuilding of Oromo national organizations and institutions started with the emergence of the Macha Tulama Association and the Oromo Liberation Front (OLF) and currently consolidated by the Qeerro/Qarree-led Oromo national movement ${ }^{3}$. Currently the commercialization and fragmentation of Oro${ }^{3}$ The accumulated grievances, the recent intensification of land grabbing policies, massive poverty, gross human rights violations, and the broadening of the political consciousness of the Oromo in general and the youth, in particular, have resulted in the Oromia-wide peaceful youth protest movement. The Qeerroo/Qarree protest movement erupted in Ginchi, near Ambo, not far from Finfinnee (Addis Ababa-the capital city), on November 12, 2015, and shortly covered all of Oromia like wild fire. The Oromo elementary and secondary students of this small town ignited the peaceful protests because of the privatization and confiscation of a small soccer field and selling of the nearby Chilimoo forest to be cleared and deforested. Supporting the peaceful protests of these students and opposing the so-called Addis Ababa master plan, the entire Oromo population from all walks of life joined the peaceful protests. 
mo ideologies and politics by different Oromo political organizations and the absence of strong national organizational capacity are the two major pitfalls of the Oromo national interest. At the same time, the availability of political opportunities such as politicized collective grievances; the existence of the OLF and other Oromo political organizations; the increase of politically consciousness among students and others; the activities of legal Oromo political organizations; the cultural renaissance initiated by the MTA and students; the further development of national Oromummaa; and the introduction of technological innovations such as social media including mobile phones, internet and tweets, satellite TVs, and radios have galvanized the Oromo people in general and the youth in particular to engage in the clandestinely organized and systematically networked peaceful protest movement that mobilized almost all sectors of the Oromo society.

As we shall see below, this movement has produced far-reaching consequences for the Oromo national struggle and politics. It has already demonstrated that the foundation of the Ethiopian colonial state has been built on a shaky foundation that cannot survive the determined and organized Oromo revolutionary force. For the first time, since their colonization the Oromo people under the leadership of qeerroo/qarree have demonstrated that they are capable of dismantling Ethiopian colonialism and its political structures. Particularly, the Oromo youth have changed the potential of the Oromo nation into collective action by uniting most sectors of the Oromo society. As a consequence of the recent Oromo protests, politically conscious Oromo and others have realized that it is only the matter of time before the Oromo nation achieves its political objective of national self-determination and democracy. Farsighted political activists and serious nationalists have realized that without building strong national institutions and organizations protests or revolts alone may not necessarily lead to a regime change in the Ethiopian empire. Developing new political strategies, building broad-based alliances, and working on building strong national institutions and political organizations are absolutely necessary to bring the Oromo national struggle to fruition. The Oromo youth protest movement has created conducive conditions for these factors. The political agenda of combining the principles national self-determination and egalitarian multinational democracy has resulted in creating consensus among the Oromo and Amhara youths and others to remove the Tigrayan-led authoritarian-terrorist regime (Jalata, 2016).

At the same time, the series of protests created a serious crisis in the Oromo People's Democratic Organization (OPDO) and led to the stepping down of the president of the Regional State of Oromia, Muktar Kedir (2014-2016), and his replacement by Lemma Megersa in October 2016. The election of Lemma Megersa was a special event because for the first time the OPDO elected its popular leader without asking for permission from the Tigrayan People's Liberation Front (TPLF), which dominated the Ethiopia government. So, we can say that the qeerroo/qarree movement has initiated the process of the liberation of OPDO from the yoke of their masters although the organization is still a mem- 
ber of the Ethiopian Peoples Revolutionary Democratic Front (EPRDF), which was dominated and led by the TPLF almost for twenty-seven years. As the qeerroo/qarree peaceful movement consolidated its political base in Oromia and extended its solidarity to other regional states, such as the Amhara youth movement ${ }^{4}$ known as Fanoo and the Gurage movement known as Zurba. As economic boycotts intensified in Oromia between June 2016 and February $2018^{5}$, to suppress the peaceful protests the TPLF/EPRDF regime declared another State of Emergence on February 16, 2018: “This is Ethiopia's second state of emergency in two years and it came a day after Prime Minister Hailemariam Desalegn resigned. The election of a new prime minister is expected early next week."

The Oromo peaceful movement assisted the OPDO to empower itself and to negotiate with the EPRDF to appoint its member, Abyi Ahmed, to become the Prime Minister of Ethiopia on April 2, 2018. Abyi Ahmed served in the Ethiopian military and rose to the rank of Lieutenant Colonel, and directed the Information Network and Security Agency, which is responsible for cyber-security and control of the Internet. He is also the Chairman of the OPDO/EPRDF, and it is not yet clear whether he has total control on the apparatuses of the Security and the Military, which are still dominated by the TPLF military leaders. Our doubt of his power is increased by the displacement of 1.2 million Oromo and the killings of hundreds of them in the Ethiopian Somali Regional State and on the borders between Oromia and the Ethiopian-Somali. Currently, the Gumuz people from Benishangul has killed many people and expelled more than eighty thousand Oromo and Amhara. From their region. Whether Lemma Megersa and Abyi Amhed, as the inheritors of gadaa, are going to repeat the golden history of Solon and Cleisthenes of ancient Athens ${ }^{7}$ in helping democracy to emerge and flourish in Oromia and Ethiopia, or whether they are going to repeat the histories of criminal dictators, namely Menelik, Haile Selassie, Mengistu Haile Mariam, and Meles Zenawi, will be known soon. Whatever political posi${ }^{4}$ https://www.garda.com/crisis24/news-alerts/90136/ethiopia-three-day-strike-in-amhara-and-orom ia-regions-feb-12-14, accessed on 7/16/2018.

${ }^{5}$ https://bawza.com/2018/03/05/boycott-oromia-protest-state-emergency/, accessed on 7/16/2018. ${ }^{6}$ https://www.washingtonpost.com/world/africa/ethiopian-lawmakers-approve-state-of-emergency/ 2018/03/0, accessed on 7/16/2018.

${ }^{7}$ The development of Athenian democracy should be considered within broader contexts such as revolutionary social conditions, volatile mass and elite relations, Solon's and Cleisthenes' reforms, and democratic political consciousness. The oppression and exploitation of ordinary people by aristocrats and landlords gradually resulted in social upheavals and ruptures that facilitated political reforms and later the emergency of democracy in Athenian society. In 594 B.C., to deal with the danger of the survival of the state, the council of Areopagus elected Solon as an "archon and reconciler." Solon was empowered by the existing socio-political conditions to introduce far-reaching reforms, which included the cancellation of rural debts, the creation of a council of 400, a law court in which the poor could serve as jurors, new laws, and constitutional reforms. He opened the political system for different classes; as a result, the laborers (thetes) were admitted to the assembly and the law courts. Returning from exile, Cleisthenes introduced some changes to the constitutional order that were passed by the citizen assembly. As Ober (2007: p. 89) notes, "The revolution was ... a necessary condition for the emergence of democracy ... The energy released by the revolution was a key factor in Athens' subsequent political evolution: in short term in the 'Cleisthenic' innovations affecting citizenship, local authority, the advisory council, the army, and control over leaders." He also reformed the Athenian administration by redistricting it into a ten diluted local/tribal boundaries to reduce stiff rivalry among tribes and prevent domination (Ladha, 2003). 
tion they take, the struggle for national self-determination and egalitarian multicultural democracy is constructed on strong cultural foundations such as the gadaa/siqqee system and other progressive cultural capital of the oppressed, exploited, terrorized, and dehumanized peoples.

\section{Major External and Internal Challenges}

The Oromo national struggle still faces serious challenges from its external and internal enemies, despite the fact that it is progressing toward determining the political destiny of the Oromo nation. Although national Oromummaa is blossoming and the Qerroo/Qaree-led Oromia-wide movement is defeating the ideology of Ethiopianism or Amhara-Tigrayan supremacy and intensifying the crisis of the empire, the tottering Ethiopian regime is still in power claiming to reform itself under the leadership of Abiy Ahmed, the prime minister of Ethiopia, because of the absence of Oromo national organizational capacity. At this historical moment, the commercialization and fragmentation Oromo ideologies and politics by Oromo political elites have undermined the development of an Oromo national organizational capacity. Oromo nationalists are divided and formed political organizations that are not yet capable of mobilizing all Oromo human, economic and intellectual resources for building the Oromo national organizational capacity, despite the fact that the Qerroo/Qarree led Oromo movement has laid the ground for the ideological unity of the Oromo national struggle. When most Oromo elites and others believe that the Lemma-Abyi team should be supported in their efforts of facilitating the process of democratic transition, the reactionary forces are clandestinely organizing and attempting to abort the transition by assassinating Abyi. Although they failed, these forces tried to murder the popular Oromo prime minister twice.

In order to prevent the abortion of the transition to democracy, all progressive forces in general and the Oromo movement in particular should support the efforts of democratic transition led by the Lemma-Abyi team. Since the Oromo movement is the backbone of this transition, all Oromo political forces including the progressive elements in the OPDO need to stop the commercialization and fragmentation of Oromo politics and combine their human, material and ideological resources to build the Oromo national organizational capacity, which is absolutely necessary to protect the Oromo national interest at this historical period. Protecting the Oromo national interest requires a clear understanding of the essence Oromo national institutions and organizations and their differences and roles and interactions. Institutions, according to Dogulass North (1995: p. $15)$, are "the rules of the game," and organizations are the players or the agents in a society. In other words, social "institutions are the constraints that human beings impose on human interaction. They consist of formal rules (constitutions, statute law, common law, and regulations) and informal constraints (conventions, norms, and self-enforced codes of conduct) and their enforcement characteristics. These constraints define (together with the standard constraints of economics) the opportunity set in the economy" and politics. Institutions 
produce and maintain "some regularity in collective behavior" in a given society in order to influence individuals to behave similarly in the same social condition.

Institutions enable a society to solve their collective problems by establishing collectivity and solidarity among groups of individuals: "Social institutions provide groups of individuals with the means of resolving collective action problems and provide benefits for collective activity. On these accounts, institutional maintenance and stability are primarily explained by the capacity of institutions to produce collective goods or benefits for social groups." Without any questions, institutions play a central role in the processes of socioeconomic reproduction, socialization, preservation or change of social order, transmission of culture, and personality development. In satisfying human needs, institutions create and maintain social solidary and cohesion among members of a society to facilitate collective action. All institutions produce and preserve social norms by transmitting them to members of a given society. Every society establishes its norm as a property of its social system at micro and macro levels to differentiate proper or correct behaviors and actions from improper or incorrect behaviors and actions by rewarding the former ones and punishing the latter ones. Social norms and state institutions assist to maintain a social order or a social system.

As the case of the Oromo demonstrates, colonial institutions have negatively changed the people by imposing violence such as terrorism and genocide to exploit their economic and labor resources. Whether collective behaviors or norms are produced spontaneously or designed consciously or by both, all societies need their independent institutions to collectively solve their problems. It is necessary to clearly comprehend the differences between the institutions of the colonizers and the colonized. In the capitalist world system, the elites and their supporters "have ... perceived the game as one where the highest rewards accrued to military conquest, exploitation (such as enslavement [and colonization]), formation of monopolies, and so forth; in consequence, the kinds of skills and knowledge invested in have been aimed at furthering such policies" (North, 1995: p. 19). The impact of Ethiopian colonialism, the erosion of Oromo national norms, political commercialization and fragmentation, the disconnection between local interests and national interests, and uneven development of Oromo nationalism (national Oromummaa) are the major challenges for building a unified Oromo national institution or organization. Without rebuilding strong national institutions, the Oromo cannot transform their numerical strength, abundant economic resources, and the determination of nationalists to national organizational power that can empower the nation.

The immediate challenge the Oromo face as a nation is accepting that they do not have strong national institutions and organizations that can empower the Oromo people at this moment. Another challenge that the Oromo nationalists face today is reshaping Oromo norms and behaviors toward building formidable national institutions and civic and political organizations. The Oromo do not have another model, except critically and thoroughly learning about the Oromo democratic traditions and rebuilding national consensus through honest, open 
and democratic deliberations. The Oromo choice is either to reshape their current political norms and behaviors and the way they deliberate their politics in order to rebuild their democratic national institutions and organizations in order to build egalitarian multinational democracy or to perpetuate the existing status quo of fragmentation and disempowerment and suffer under the authoritarian-terrorist state of Ethiopia. The fragmented Oromo political organizations and national leadership should be stopped by the Oromo people by forcing Oromo organizations and their leadership to negotiate and collaborate with one another on the Oromo liberation project and to protect the Oromo national interest. The various Oromo leadership must also be challenged to move from an initial reliance on a narrow political circle and borrowed political ideologies and practices, and to embrace Oromo-centric democratic values to organize different forms of leadership in the Oromo society by establishing dynamic connections with the Oromo people.

All Oromo nationalists should participate in revitalizing the Oromo national movement through the application of elements of gadaa/siiqqee principles by aiming at the consolidation of a democratic Oromia state and/or shared sovereignty with others by implementing internal peace within the Oromo national movement and the Oromo society and by promoting peace (nagaa Oromoo) with Oromo neighbors. The refining and adaptation of the best elements of the gadaa/siqqee system are necessary to strengthen and consolidate the Oromo national struggle in order to protect the Oromo national interest. The Oromo national movement needs to retrieve, refine, adapt, and practice the principles of gadaa/siqqee (Kelly, 1992; Kumsa, 1997). The idea of building a national Gumii Oromiyaa must be given top priority by all Oromo and their political and civic organizations in order to revitalize, centralize, and coordinate the Oromo national movement and protect the Oromo national interest. Oromo nationalist leaders need to start to search for ways of enabling all Oromo to participate in the Oromo national movement by providing ideas, resources, expertise, and their labor. Although the fire of Oromo nationalism was lit by a few, determined revolutionary elements, the Oromo national struggle has now reached the level where it requires mass mobilization and participation. In this mobilization, the Oromo national movement should use the ideology and principles of gadaa democracy, which must be enshrined in national Oromummaa in order to mobilize the entire nation spiritually, financially, militarily, and organizationally to take coordinated political and military action.

In order to obtain political legitimacy from the Oromo society even the enemy of the Oromo people uses the discourse of gadaa without believing in it and practicing its principles. Despite the fact that the contemporary organizations of the Oromo national movement use gadaa names or concepts, they rarely apply the principles of the system to regulate their own political behavior and practices. According to Oromo political traditions, rules and laws are made through serious debates, and once decisions have been made by the general assembly both leaders and citizens are obligated to implement them. Nobody is above the rule 
of law. Although it is challenging and difficult to implement all relevant gadaa principles while engaging in the liberation struggle, Oromo organizations must agree on certain principles and initiate pragmatic policies that embody Oromo democracy if they are struggling to restore Oromo statehood, sovereignty, and democracy. Certain gadaa principles that Oromo political and civic organizations need to immediately adapt include the rule of democratic laws, periodic succession of leadership, moral and ethical integrity, honesty, democratic public deliberations, the sovereignty of the people and defeating the collaborator of the enemy, and building national political consensus. By mobilizing gadaalsiiqqee experts and Oromo intellectuals who are familiar with the Oromo democratic traditions, the Oromo national movement should start to formulate procedures, strategies, and tactics for the building of the supreme authority of a national assembly may be called Gumii Oromiyaa. At this national Gumii, all Oromo liberation fronts and organizations that can carry out their national obligations, all representatives of Oromo civil and religious organizations, and representatives of all Oromo sectors must be included.

This national Gumii can be modeled after the Gumii Gayyo (Huqqa, 1998). The Gumii Gayyo is an expression of the exemplar model of the unwritten Oromo constitution. Reframing the unwritten Oromo constitution and transforming into a new national constitution based on Oromo democratic principles require absolute commitment from Oromo nationalists and their organizations rather than giving lip service to this idea. By establishing the National Assembly of Gumii Oromiyaa, Oromo nationalists and organizations of the Oromo national movement can initiate the process of framing a written Oromo constitution by adapting the received tradition to new circumstances while learning from other democratic traditions. If Oromo nationalists and organizations are truly concerned about their people and if they want to win their national struggle, they need to show respect for their democratic traditions and practice civility in their political and ideological deliberations. Such responsible and courageous actions require taking accountability seriously and using a single standard for evaluating behavior and measuring performance in relation to the Oromo national struggle. To build Gumii Oromiyaa, the Oromo national movement needs to address five major issues. The first issue is to develop national Oromummaa to its full capacity by overcoming its unevenness and deficiencies in order to strengthen the Oromo national organizational capacity. After Oromo were colonized and until Oromo nationalism emerged, Oromoness primarily remained on the personal and the interpersonal levels because Oromo were denied the opportunities to form national institutions and organizations ${ }^{8}$. Consequently, today the Oromo elites who have internalized these externally imposed regional or ${ }^{8}$ Oromoness was targeted for destruction and colonial administrative regions that were established to suppress the Oromo people and exploit their resources were glorified and institutionalized. As a result, Oromo relational identities have been localized, and not strongly connected to the collective identity of national Oromummaa. Oromo have been separated from one another and prevented from exchanging goods and information for more than a century. They were exposed to different cultures (i.e., languages, customs, values, etc.) and religions and adopted some elements of these cultures and religions. 
religious identities because of their low level of political consciousness or political opportunism, and the lack of clear understanding of national Oromummaa.

Without critically retrieving and restoring Oromo cultural and historical resources and using them in developing Oromo nationalism, it is difficult to build a national political agenda. Oromo who did not yet develop national political consciousness may confuse clan or regional or religious politics with the Oromo national politics because of the lack of the comprehension of the consequences of their political behaviors and actions. As one can learn from history, the Oromo political weakness mainly emerged as Oromo moved away from one gadaa republic and started to form autonomous gadaa governments in different parts of Oromia. Hence, the building of the Oromo national organizational capacity is only possible when national Oromummaa is fully developed and can be packaged into a generally accepted vision that energizes the entire Oromo nation to undertake a well-organized and coordinated collective action at the personal, interpersonal and national levels. As an element of culture, nationalism or national Oromummaa has the power to serve as a manifestation of the collective identity of the Oromo national movement. The basis of national Oromummaa must be built on overarching principles that are embedded within Oromo democratic traditions and culture and, at the same time, have universal relevance for all oppressed peoples. The main foundations of national Oromummaa are individual and collective freedom, justice, popular democracy, and human liberation, which are built on the concept of safuu (Oromo moral and ethical order) and are enshrined in gadaa/siiqqee principles. As the ideology of the Oromo national movement, national Oromummaa enables Oromo to retrieve their cultural memories, assess the consequences of Ethiopian colonialism, and give voice to their collective grievances.

As such, national Oromummaa can mobilize diverse cultural resources, interlink Oromo personal, interpersonal and collective (national) relationships, and assists in the development of Oromo-centric political strategies and tactics that can mobilize the nation for collective action and empower the people for liberation. As the shared ideology of the Oromo national movement, national Oromummaa requires that the movement be inclusive of all persons operating in a democratic fashion. National Oromummaa enables the Oromo people to form alliances with all political forces and social movements that accept the principles of national self-determination and egalitarian multinational democracy in the promotion of a global humanity that is free of all forms of oppression and exploitation. The Oromo are struggling for national self-determination and an egalitarian multinational democracy because there are other peoples in Oromia and beyond with which they can share statehood and sovereignty based on Oromo democratic traditions. The Oromo movement respects the rights and political aspiration of other peoples beyond Oromia and invites them to create solidarity and form alliance with the Oromo nation. The second issue deals with the necessity of building strong national capacity. Oromo organizations must develop commitment to refine and apply some elements of gadaa/siiqqee principles and 
to rebuild a new national Gumii Oromiyaa. The starting point to initiate the formation of the new national Gumii Oromiyaa can be the rebuilding of Oromo national capacity by Oromo political organizations and nationalists to work together while maintaining their autonomous existence and fashioning a new approach to build this national assembly.

Furthermore, Oromo civic, cultural, and religious associations and other Oromo sectors should be partners in building this Oromo national assembly. Oromo nationalists do not need to wait to form the national Gumii Oromiyaa until liberation. Gumii Oromiyaa as a political and cultural platform can provide a mechanism for establishing a common understanding and consensus among the fragmented Oromo political forces provided that it will be wisely and carefully handled. Oromo nationalists should be clear that the Oromo national movement is not struggling to reinvent the moottii system or Oromo chiefdoms based on clans or regions. In some parts of the Oromo society, the emergence of the moottii system undermined the gadaa system and later facilitated the formation of those Oromo forces that collaborated with the Ethiopian colonial system. As other nationalisms, Oromo nationalism has two edges, the one edge cutting backward, and the other forward. The Oromo national movement should reconsider Oromo culture and history, and recognize the negative ones and avoid them. As the formation of different autonomous gadaa governments and the emergence of the moottii system contributed to the defeat of the Oromo people in the second half of the $19^{\text {th }}$ century, the political fragmentation of the Oromo society will perpetuate the defeat of the Oromo nation in the $21^{\text {st }}$ century. Without the coordination and the consolidation of the Oromo national movement, Oromo cannot effectively confront and defeat the Ethiopian colonial system and its Oromo collaborator class.

Oromo liberation organizations have a historic responsibility to cooperate with one another and participate in the Oromo national movement in order to reach larger audiences, share resources as well as experiences, and gain political legitimacy. It is essential that they end their internecine squabbles and negative political propaganda against one another. This does not mean that Oromo organizations should not be scrutinized and evaluated in relations to their objectives, ideologies, and performance. Thirdly, while consolidating the Oromo national movement, it is necessary to build political alliances with peoples who are interested in the principles of national self-determination and egalitarian multinational democracy. Although the priority of the Oromo national movement is to liberate the Oromo people, the movement has moral and political obligations to promote social justice and democracy for the peoples who have suffered under the successive authoritarian-terrorist governments of the Ethiopian Empire. Therefore, the Oromo movement needs to build a political alliance with national groups that endorse the principles of national self-determination and egalitarian multinational democracy. A democratic sovereign Oromia should play a central role in a multinational democratic state because of its democratic tradition, the size of its population, geopolitics, and abundant economic resources. By framing 
a democratic constitution based on Oromo democratic principles and other democratic traditions, the national assembly of Gumii Oromiyaa should demonstrate to the Oromo society and their neighbors that the Oromo nation is serious about statehood, sovereignty, and egalitarian multinational democracy for the Oromo and others.

This brings us to the fourth issue: This is the obligation of every Oromo for restoring Oromian sovereignty and statehood as a state within a multinational context. The Oromo national struggle manifests the aspiration of all Oromo. Therefore, every Oromo has moral, political and national obligations to actively participate in the Oromo national struggle to enable the Oromo nation to achieve its political, social, and economic objectives. Particularly, Oromo intellectuals have great responsibility to mobilize all Oromo and others on the principles of self-determination, social justice, and egalitarian multinational democracy, and to expand the leadership capacity of the Oromo movement. Therefore, the expansion of the national leadership capacity is the final issue. The responsibilities of Oromo intellectuals also include developing pragmatic policies that will lay the foundation of both an Oromian democratic state and an egalitarian multinational state, establishing special relationship with the colonized nations in the Ethiopian Empire, expanding public diplomacy by consolidating the support of the Oromo diaspora, and influencing world powers by using the principles of global Oromummaa to support the just cause of the Oromo for social justice, liberation, and democracy. The final issue is expanding the national leadership capacity of this movement by mobilizing the active participation of Oromo women and youth that can be more than the two-third of the Oromo population. These two important sectors of the Oromo society must actively participate in the Oromo national movement and in the formation of the national assembly of Gumii Oromiyaa.

\section{Conclusions}

The protection of the Oromo national interest requires restoring the best elements of the gadaa/siqqee principles, reinventing an Oromia democratic state in a multinational context, and building an Oromia formidable defense force, which incorporates the Oromo Liberation Army of the Oromo Liberation Front. These are important political steps that are required to stop the systematic attack and terrorism on the Oromo people in Oromia and in different regional Ethiopian states, such as the Somali, Afar, Amhara, the Southern Nations and Nationalities and Peoples Regional State, and Benishangul, as well as in Finfinnee (Addis Ababa) and its surroundings. The first subset of the Oromo national interest is the protection of what the Oromo struggle has achieved up to now. These achievements include the development of Oromo national identity and nationalism; the development of qubee (the Oromo alphabet) and the restoration of the Oromo language; the geopolitical demarcation of Oromia and the creation of the Oromia Regional State through federalism; the revival of Oromo culture and national unity through restoring certain elements of gadaa/siqqee; 
the efforts of protecting Oromo lands and other resources; and the efforts of liberating Oromo collaborators from the yoke of the enemy by empowering them through developing the psychology of liberation and victorious consciousness to overcome their inferiority complex. The second subset of the Oromo national interest is to maintain the commitment of the Oromo people, which is demonstrated under the leadership of qeerroo/qarree to achieve popular sovereignty, statehood, and egalitarian multinational democracy. The protection of these achievements is absolutely necessary to move toward protecting the Oromo national interest.

The immediate task for the Oromo political and civic institutions and organizations should be to agree upon creating the democratic rules of the game based on acceptable national norms and behaviors and values that reflect safuu and Oromo democracy (Legesse, 1987, 2006 [2000]) in order to protect the Oromo national interest. The next task is to build formidable national institutions and organizations that will empower the Oromo nation to determine its national destiny. All concerned Oromo are agents who can contribute something to change the deplorable condition of their people. It is wrong to be neutral and silent when the Oromo people are facing terrorism and genocidal massacres by Tigrayan colonial elites and their collaborators. Particularly, the diaspora Oromo have moral and ethical responsibilities to maintain safuu and to get organized to support the struggle of their people; they must also stop those who engage in divisive activities that facilitate the perpetual suffering of their people. History aptly demonstrates that people can revolt and overthrow regimes, but they cannot form their own democratic government without having their strong national institutions and organizations. All Oromo nationalists and organizations are required to be united for building an Oromo national organizational capacity, which insures the survival of the Oromo nation and protects its national interest.

\section{Conflicts of Interest}

The author declares no conflicts of interest regarding the publication of this paper.

\section{References}

Baissa, L. (1971). The Democratic Political System of the Galla [Oromo] of Ethiopia and the Possibility of its Use in Nation-Building. M.A. Thesis, George Washington University.

Baissa, L. (1993). The Political Culture of Gada: Building Blocks of Oromo Power. Paper Presented at the Oromo Studies Association Conference, 31 July-1 August 1993, Canada: University of Toronto.

Baissa, L. (2004). The Oromo Gadaa System of Government: An Indigenous African Democracy. In A. Jalata (Ed.), State Crises, Globalisation and National Movements in Northeast Africa (pp. 101-121). New York: Routledge.

Bulcha, M. (2016). Contours of the Emergent \& Ancient Oromo Nation (Second Revised Edition). Cape Town: CASAS. 
Etefa, T. (2012). Integration and Peace in East Africa: A History of the Oromo Nation. New York: Palgrave. https://doi.org/10.1057/9781137091635

Hassen, M. (1990). The Oromo of Ethiopia: A History 1570-1860. Cambridge: Cambridge University Press.

Hassen, M. (2015). The Oromo \& the Christian Kingdom of Ethiopia 1300-1700. London: James Currey.

Huqqa, G. (1998). The 37th Gumii Gaayo Assembly. Addis Ababa: The Norwegian Church Aid.

Jaarrraa, T. A., \& Saaddoo, M. H. A. (2011). Seenaa Oromo Fi Madda Walaabuu (History of the Oromo and Madda Walaabuu). Self-Published.

Jalata, A. (2001). Fighting Against the Injustice of the State and Globalization: Comparing the African American and Oromo Movements. New York: Palgrave. https://doi.org/10.1057/9780312299071

Jalata, A. (2005 [1993]). Oromia \& Ethiopia: State Formation and Ethnonational Conflict, 1868-2004. Lawrenceville, NJ: The Red Sea Press.

Jalata, A. (2007). Oromummaa: Oromo Culture, Identity and Nationalism. Atlanta, GA: Oromia Publishing Company.

Jalata, A. (2010). Contending Nationalisms of Oromia and Ethiopia: Struggling for Statehood, Sovereignty, and Multinational Democracy. Binghamton: Global Academic Publishing, Binghamton University, State University of New York.

Jalata, A. (2016). Phases of Terrorism in the Age of Globalization. New York: Palgrave Macmillan. https://doi.org/10.1057/9781137552341

Kelly, H. A. (1992). From Gada to Islam: The Moral Authority of Gender Relations among the Pastoral Orma of Kenya. Ph.D. Dissertation, Los Angeles: University of California.

Kumsa, K. (1997). The Siiqqee Institution of Oromo Women. The Journal of Oromo Studies, 4, 115-152.

Ladha, K. K. (2003). Kleisthenes and the Ascent of Democracy. https://www.cerge-ei.cz/pdf/events/papers/031016_t.pdf

Legesse, A. (1973). Gadaa: Three Approaches to the Study of African Society. New York: Free Press.

Legesse, A. (1987). Oromo Democracy. In Conference on the Oromo Revolution.

Legesse, A. (2006, 2000). Oromo Democracy: An Indigenous African Political System. Lawrenceville, NJ: Red Sea Press.

Lepisa, D. (1975). The Gada System of Government and Sera Cafee Oromo. LLB Thesis, Addis Ababa: Addis Ababa University.

Lewis, H. S. (2001). Jimma Abba Jifar: An Oromo Monarchy. Lawrenceville, NJ: The Red Sea Press, Inc.

North, D. C. (1995). Five Propositions about Institutional Change (pp. 15-26). Ann Arbor: The University of Michigan Press.

Ober, J. (2007). I Besieged That Man: Democracy's Revolutionary Start. In K. A. Raaflaub, J. Ober, \& R. W. Wallace (Eds.), Origins of Democracy in Ancient Greece (pp. 83-104). Berkeley, CA: University of California Press.

Oromia Culture and Tourism Bureau OCTB (2006). History of the Oromo to the Sixteenth Century(2nd ed.). Finfinnee: Berhanena Selam Printing Enterprise.

Rodney, W. (1972). How Europe Underdeveloped Africa. Washington DC: Howard Uni- 
versity.

Ta'a, T. (1986). The Political Economy of Western Central Ethiopia: From the Mid-16th to the Early-20th Centuries. PhD Dissertation, East Lansing, MI: Michigan State University. 